\title{
ANALISIS PROSES MUTASI PROMOSI JABATAN PEGAWAI NEGERI SIPIL DI KANTOR BADAN KEPEGAWAIAN DAERAH KABUPATEN GOWA
}

\author{
*Edyanto ${ }^{1)}$ \\ 1) Progam studi Ilmu Pemerintahan, Fakultas Ilmu Sosial dan Ilmu Politik, Universitas \\ Muhammadyah Sorong, Indonesia \\ *Email Korespondensi : edypapua10@gmail.com
}

\begin{abstract}
Abstrak
Aktivitas mutasi kepegawaian yang paling menonjol di Kabupaten Gowa adalah dalam rangka promosi jabatan dan pemindahan dalam rangka distribusi pegawai secara merata di jajaran Dinas, Badan dan Kantor di Kabupaten Gowa. Jenis penelitian yang dianggap tepat dalam penelitian ini adalah metode deskriptif dengan pendekatan secara kualitatif. Pengumpulan data penelitian ini dilakukan dengan berpedoman pada observasi, interview dan dokumen. Teknik analisis data yang digunakan dalam penelitian ini teknik analisis taksonomis (taxonomis analysis), yaitu membentuk analisis secara rinci dan mendalam dalam membahas suatu tema atau pokok permasalahan. Analisis taksonomi ini digunakan untuk menjabarkan secara rinci proses mutasi promosi jabatan pegawai negeri sipil di Kantor Badan Kepegawaian Daerah Kabupaten Gowa. Berdasarkan hasil penelitian, dalam hal mutasi pegawai negeri sipil, maka kewenangan yang ada pada pemerintah sangat luas. Hanya pengangkatan eselon II yang perlu mendapatkan persetujuan dari pemerintah tingkat atasnya, dan pengangkatan Sekwilda yang mendapatkan persetujuan dari DPRD setempat. Prosedur untuk mutasi pegawai, berbeda sesuai dengan kedudukan dari mutasi tersebut. Untuk mutasi karena promosi, maka telah ditetapkan berdasarkan perundang-undangan yang berlaku.
\end{abstract}

Kata Kunci: Mutasi; Promosi Jabatan; Pegawai Negeri Sipil

\begin{abstract}
The most prominent employee transfer activity in Gowa Regency is in the context of promotion and transfer to distribute employees evenly in the ranks of Offices, Agencies and Offices in Gowa Regency. The type of research that is considered appropriate in this research is descriptive method with a qualitative approach. The research data collection was carried out based on observations, interviews and documents. The data analysis technique used in this study is a taxonomic analysis technique, which is to form a detailed and in-depth analysis in discussing a theme or subject matter. This taxonomic analysis is used to describe in detail the process of transferring a promotion to a civil servant position at the Regional Civil Service Agency Office of Gowa Regency. Based on the research results, in terms of the transfer of civil servants, the government has very broad authority. Only echelon II appointments need to get approval from the top-level government, and Sekwilda appointments that get approval from the local DPRD. The procedures
\end{abstract}


for transferring employees differ according to the position of the transfer. For transfer due to promotion, it has been determined based on the applicable laws.

Keywords: Movements; Promotion of Position; Civil Servants

\section{PENDAHULUAN}

Sejak berlakunya Undang - Undang Nomor 22 Tahun 1999 tentang Pemerintahan Daerah, yang kemudian menjadi Undang - Undang Nomor 32 Tahun 2004 sebagian kewenangan diberikan kepada pemerintah daerah kabupaten/ kota. Kemandirian daerah untuk kegiatan mutasi kepegawaian, terletak pada kewenangan daerah sebagaimana diatur dalam pasal 130 ayat 2 Undang - Undang Nomor 32 Tahun 2004, di mana dikatakan bahwa pengangkatan, pemindahan, dan pemberhentian dari dan dalam jabatan eselon II pada pemerintah daerah kabupaten / kota ditetapkan oleh Bupati / wali kota setelah berkonsultasi kepada gubernur dan mendapat persetujuan dari gubernur (Bratakusumah, 2001). Oleh sebab itu dalam kegiatan mutasi kepegawaian, maka pembinaan kepegawaian harus tetap dipandang sebagai satu kesatuan pembinaan kepegawaian secara nasional.

Hal ini juga berkaitan dengan pendapatan atau gaji yang diterima oleh pegawai negeri sipil, yang ditetapkan oleh pemerintah pusat dan dibayar melalui APBD yang sumbernya berasal Dana Alokasi Umum (DAU)(Sarwono, 2011) . Saat terjadi mutase kepegawaian yang disebabkan oleh perpindahan karena kenaikan jabatan maka harus diikuti dengan kenaikan tunjangan jabatan atau kenaikan pendapatan dan tentu tetap harus melibatkan pemerintah tingkat atasnya (Fanhar, 2016). Oleh sebab itu dalam mutasi atau perpindahan pegawai di jajaran pemerintahan daerah Kabupaten / Kota prinsip koordinasi dengan Pemerintah Provinsi dan Pemerintah Pusat dalam hal ini Badan Kepegawaian Negara $(\mathrm{BKN})$ tetap harus berjalan sebagaimana mestinya.

Konsekuensi dari pelaksanaan otonomi daerah yang memberikan kewenangan yang luas kepada Pemerintah Daerah termasuk bidang kepegawaian itu sendiri (Sani, 2016). Meskipun harus diakui bahwa kemandirian kewenangan daerah dalam mengurus kepegawaian di daerah masih sangat terbatas, bahkan saat ini sistem pembinaan kepegawaian kembali bersifat sentralistik setelah sebelumnya pernah berlaku sistem desentralistik saat berlakunya Undang - Undang Nomor 22 Tahun 1999 hingga keluarnya Undang - Undang Nomor 32 Tahun 2004. Kemandirian daerah dapat diartikan bahwa 
adanya kemampuan dan kewenangan daerah yang dapat dilakukan tanpa intervensi dari pihak lain baik pemerintah atasnya, maupun oleh kekuatan politik.

Oleh sebab itu, kemandirian daerah dalam melakukan mutase seharusnya merupakan kewenangan pemerintah daerah, berdasarkan kebutuhan-kebutuhan yang diperlukan dimasing-masing daerah (Putro \& Sugiyarti, 2012). Sedangkan pemerintah tingkat atasnya baik pusat maupun Gubernur hanya bersifat koordinasi, terutama untuk eselon II sebagaimana diatur dalam pasal 130 ayat 2 Undang - Undang Nomor 32 Tahun 2004, dimana dikatakan bahwa pengangkatan, pemindahan dan pemberhentian dalam jabatan eselon II pada pemerintah daerah kabupaten / kota ditetapkan oleh Bupati / Walikota setelah berkonsultasi kepada Gubernur dan mendapat persetujuan dari Gubernur. Sedangkan untuk perpindahan dan pengangkatan pegawai dalam jabatan dibawahnya merupakan kewenangan Bupati Kepala Daerah, yang dilaksanakan oleh Badan Kepegawaian Daerah (Fanhar, 2016). Oleh sebab itu Badan Kepegawaian Daerah dalam melaksanakan tugas bertanggung jawab kepada Bupati melalui Sekretaris Daerah Kabupaten.

Berdasarkan data penempatan dan mutasi pegawai di lingkup Badan Kepegawaian Daerah Kabupaten Gowa Tahun 2013/2014, maka terlihat adanya beberapa pegawai yang memperoleh mutasi karena alasan promosi, namun terkesan kurang sesuai dengan latar belakang kompetensinya, terutama dilihat latar belakang pendidikan pegawai tersebut. Seperti adanya pegawai yang ditempatkan pada suatu jabatan namun latar belakang pendidikannya yang berbeda. Kondisi ini tentu memberikan kesan bahwa proses mutasi pegawai yang dilaksanakan mengikuti keinginan masing-masing individu, tanpa memperhitungkan tujuan organisasi secara keseluruhan, seharusnya ada keselarasan dalam tujuan individu pegawai dan tujuan organisasi.

Administrasi sebagai usaha kerjasama manusia muncul bersama dengan timbulnya peradaban manusia melalui kemampuannya untuk menggunakan pikirannya sehingga melahirkan cipta, karsa dan rasa (Rahman, 2017). Pengembangan cipta dan karsa serta rasa memungkinkan manusia dapat bekerja sama yang merupakan unsur utama dalam administrasi. Mengenai istilah administrasi di Indonesia terdapat dua macam, yaitu ditinjau dari segi asal usulnya yakni dari Bahasa Belanda dan Inggris. Istilah 
administrasi yang ditulis oleh orang Belanda adalah administratie pada umumnya berarti tata usaha, yaitu urusan pencatatan mengisi formulir, membaca informasi, menerima atau mengisi informasi, menyimpan catatan (Rahman, 2017)

(Karyana, 2014) mengemukakan bahwa Administrasi adalah suatu proses yang biasanya terdapat pada semua usaha kelompok baik usaha pemerintah atau swasta, sipil atau militer baik secara besar-besaran ataupun secara kecil - kecilan. Sedangkan menurut (Rahman, 2017) mengemukakan bahwa: Administrasi adalah keseluruhan kerjasama sekelompok manusia, dua orang atau lebih yang didasarkan pada rasionalitas tertentu untuk mencapai tujuan tertentu yang telah ditentukan. Berdasarkan pengertian diatas maka, administrasi adalah segenap rangkaian kegiatan atau aktivitas manusia yang dilakukan suatu usaha kerjasama / kelompok untuk mencapai tujuan tertentu sesuai yang telah ditentukan sebelumnya.

Istilah kepegawaian dalam bahasa asing sering disebut sebagai personnel, labour and worker man, sedangkan di Indonesia sering diterjemahkan dengan istilah pegawai, pekerja, buruh dan sebagainya. (Satoto, 2004) mengemukakan bahwa: "Kepegawaian adalah segenap aktivitas yang bersangkut paut dengan masalah penggunaan tenaga kerja manusia untuk mendapatkan sesuatu / mencapai tujuan tertentu. Masalah pokoknya berkisar pada penerimaan, pengangkatan, pengembangan pemberian balas jasa dan sampai pensiunnya". Permasalahan dalam pelaksanaan mutasi pegawai negeri sipil di lingkup tugas Badan Kepegawaian Daerah Kabupaten Gowa adalah; Pelaksanaan mutasi pegawai, terutama yang berkaitan dengan promosi belum sepenuhnya dilakukan secara obyektif dan transparans yang berpedoman pada masa kerja (karier) dan prestasi kerja, yang diindikasikan pada adanya pegawai yang menduduki jabatan belum memenuhi persyaratan jabatan, banyak pegawai yang memiliki keinginan untuk ditempatkan pada tempat yang diinginkan sesuai pilihan mereka sehingga menimbulkan dinamika mutasi kepegawaian yang berjalan di luar prosedur dan mekanisme yang tidak wajar. Dalam proses mutasi pegawai, masih kadang adanya intervensi dari elit-elit politik atau elit lokal setempat, terutama dalam hal penempatan dalam jabatan-jabatan yang dianggap strategis. Berdasarkan dari asumsi-asumsi tersebut maka penelulis tertarik untuk mengadakan 
penelitian tentang proses mutase promosi jabatan Pegawai Negeri Sipil di Kantor Badan Kepegawaian Daerah Kabupaten Gowa.

\section{TINJAUAN PUSTAKA}

Berdasarkan penelitian yang dilakukan oleh (Judas, 2013) dengan judul penelitian Motasi Dan Promosi Jabatan Pengaruhnya Terhadap Prestasi Kerja Pegawai Pada kawil Ditjen Kekayaan Negara Suluttenggo Dan Maluku Utara Di Madano. Dengan menggunakan sebanyak 48 pegawai sebagai sempel dengan menggunakan metode analisis regresi linear berganda. Tujuan dari adanya penelitian ini adalah mengetahui pengaruh mutase dan promosi jabatan dari adanya prestasi kerja pegawai pada Kanwil Ditjen Kekayaan Negara Suluttenggo dan Maluku Utara di Manado. Adanya penelitian ini dilatar belakangi oleh sebagai tindak lanjut yang telah dilakukan dari hasil penilaian prestasi kerja pegawai adalah terjadinya mutase dan promosi jabatan. Dengan adanya penilaian prestasi pegawai maka akan diketahui kecakapan pegawai dalam menyelesaikan uraian pekerjaan yang di amanahkan. Pada penelitian ini menunjukan hasil bahwa mutase tidak berpengaruh terhadap prestasi kinerja pegawai sedangkan promosi jabatan berpengaruh terhadap kinerja pegawai. Hingga dapat disimpulkan bahwa mutase dan promosi jabatan sangat berpengaruh terhadap prestasi kinerja pegawai, sehingga perlu memberikan motivasi kepada para pegawai untuk meningkatkan prestasi kerja pegawai. Karena hal tersebut merupakan kegiatan penting dalam pengembangan pegawai.

\section{METODE PENELITIAN}

Penelitian ini dilakukan di Kantor Badan Kepegawaian Daerah Kabupaten Gowa. Tipe penelitian ini adalah deskriptif dengan analisa kualitatif yang bertujuan untuk memberikan gambaran secara jelas proses mutasi promosi jabatan pegawai negeri sipil di Kantor Badan Kepegawaian Daerah Kabupaten Gowa (Miles \& Huberman, 1994). Informan pada penelitian ini merupakan pegawai yang sementara dalam proses mutasi promosi. Bentuk penelitian ini adalah Penelitian lapangan, yaitu penelitian yang menekankan penggunaan data primer yang diperoleh melalui wawancara dengan informan (Krippendorf, 2004). Peneliti melakukan observasi secara langsung kelapangan 
untuk melakukan pengamatan mengenai proses mutase promosi jabatan dengan cara melakukan telaah dokumentasi dan wawancara secara langsung oleh informan yang berada di Kantor Kepegawaian Daerah Kabupaten Gowa. Sedangkan teknik analisis yang digunakan pada penelitian ini merupakan teknik analisis taksonomis yaitu membentuk analisis yang lebih rinci dan mendalam dalam membahas suatu tema atau pokok permasalahan. Analisis taksonomi ini digunakan untuk menjabarkan secara rinci proses mutasi promosi jabatan pegawai negeri sipil di Kantor Badan Kepegawaian Daerah Kabupaten Gowa.

\section{HASIL DAN PEMBAHASAN}

\section{Proses Mutasi Berdasarkan Kewenangan Daerah}

Pelaksanaan mutasi pegawai negeri sipil sejauh ini didasarkan pada peraturan perundang-undangan yang berlaku, yaitu Undang-Undang Nomor 43 Tahun 1999 dan Peraturan Pemerintah Nomor 96 Tahun 2000 tentang wewenang pengangkatan, pemindahan dan pemberhentian pegawai negeri sipil serta Peraturan Pemerintah Nomor 100 tentang pengangkatan pegawai negeri sipil dalam jabatan struktural. Peraturan perundang-undangan tersebut disetujui oleh lembaga pembinaan dan pengembangan kepegawaian dimana mengacu pada prinsip system karier dan prestasi kerja. Dimana hanya orang yang berpengalaman dan memiliki prestasi kerja yang tinggi untuk diprioritaskan menduduki jabatan-jabatan yang telah disediakan. Khususnya jabatan yang tinggi memerlukan kemampuan teknis administratif, profesional dan memiliki loyalitas, impersonality serta integritas pribadi terhadap seluruh aspek tugas-tugasnya.

Aktivitas mutasi kepegawaian yang paling menonjol di Kabupaten Gowa adalah dalam rangka promosi jabatan dan pemindahan dalam rangka distribusi pegawai secara merata di jajaran Dinas, Badan dan Kantor di Kabupaten Gowa. Sejak berlakunya Undang-Undang Nomor 22 Tahun 1999 tentang Pemerintahan Daerah, yang kemudian diubah menjadi Undang-Undang Nomor 32 Tahun 2004, maka pelaksanaan pembinaan kepegawaian daerah sebagian kewenangan diberikan kepada pemerintah daerah Kabupaten/ Kota. Kemandirian daerah untuk kegiatan mutasi kepegawaian terletak pada kewenangan daerah sebagaimana diatur dalam pasal 130 ayat 2 Undang-Undang Nomor 
32 Tahun 2004, di mana disebutkan bahwa pengangkatan, pemindahan dan pemberhentian dari dan dalam jabatan eselon II pada pemerintah daerah kabupaten/kota ditetapkan oleh Bupati/Walikota setelah berkonsultasi kepada Gubernur. Oleh sebab itu dalam kegiatan mutasi kepegawaian maka pembinaan kepegawaian harus tetap dipandang sebagai satu kesatuan pembinaan kepegawaian secara nasional. Hal ini juga berkaitan dengan pendapatan atau gaji yang diterima oleh pegawai negeri sipil yang ditetapkan oleh pemerintah pusat dan dibayar melalui APBD yang sumbernya berasal dari Dana Alokasi Umum (DAU). Dalam hal mutasi pegawai dalam bentuk perpindahan karena kenaikan jabatan jelas juga harus diikuti dengan kenaikan tunjangan atau kenaikan pendapatan dan tentu tetap harus melibatkan pemerintah tingkat atasnya. Adapun mutasi atau perpindahan pegawai di jajaran pemerintahan daerah Kabupaten/Kota prinsip koordinasi dengan pemerintah Provinsi dan Pemerintah Pusat dalam hal ini Badan Kepegawaian Nasional $(\mathrm{BKN})$ tetap harus berjalan sebagaimana mestinya.

Pada prakteknya hal ini dapat ditunjukan dengan keikutsertaan pegawai negeri sipil dalam pendidikan dan latihan, pembinaan pegawai, serta mutasi baik mutasi dalam jabatan (promosi dan demosi) maupun mutasi tidak dalam jabatan (rotasi) antar unit ataupun wilayah kerja. Hal menarik dari isyu strategis pada pelaksanaan otonomi daerah, yang menyangkut sumber daya manusia adalah mengenai mobilitas sumber daya manusia. Mobilitas sumber daya manusia dimaksudkan agar terjadi penyebaran sumber daya manusia dalam bidang keahlian teknis tertentu agar tidak menumpuk pada satu tempat saja. Bentuk mobilitas sumber daya manusia dalam administrasi kepegawaian adalah mutasi pegawai negeri sipil baik dalam jabatan maupun tidak dalam jabatan. Terlepas dari alasan mutase pegawai negeri sipil tersebut yaitu karena alasan kedinasan maupun alasan pribadi, keduanya dapat mengambarkan upaya mobilitas distribution of resourses. Kenyataan menunjukkan bahwa di Kabupaten Gowa sampai saat ini belum sepenuhnya terjadi distribusi pegawai negeri sipil yang memadai, masih terdapat SKPD (Satuan Kerja Pemerintah Daerah) di jajaran Kabupaten Gowa mempunyai potensi sumber daya manusia secara kualitas kurang memadai dan handal untuk melaksanakan tugasnya dalam bidang keahlian tertentu yang diperlukan. Oleh sebab itu mutasi pegawai negeri sipil 
menjadi sangat penting dalam optimalisasi perputaran dalam memperbaiki formasi kepegawaian yang ada dalam pelaksanaan otonomi daerah di Kabupaten Gowa.

Pelaksanaan mutasi Pegawai Negeri Sipil dalam suatu daerah sudah sering dilaksanakan dan tidak terlalu memunculkan polemik, karena merupakan tuntutan pengembangan organisasi. Disamping itu alasan manajerial yang lebih rasional yaitu mengenai formasi, analisa jabatan, penataan organisasi dan Daftar Susunan Pegawai (DSP), selalu menjadi pertimbangan utama, meskipun juga harus diakui bahwa pertimbangan-pertimbangan dari sisi politis, menyangkut loyalitas bawahan juga menjadi isyu yang sering diketengahkan dalam pelaksanaan mutasi pegawai. Meskipun demikian dalam rangka penelitian mengenai pengembangan mutasi pegawai negeri sipil di Kabupaten Gowa, maka penulis menyoroti tiga aspek yang menyangkut mutasi pegawai negeri sipil, yaitu mutasi karena promosi, mutasi karena perpindahan biasa dan mutasi karena hukuman.

\section{Mutasi Promosi}

Mutasi karena promosi dalam tubuh pegawai negeri sipil berarti adanya pengembangan karier dalam bentuk bertambahnya kewenangan, tanggungjawab serta hak-hak yang dapat diperoleh pegawai negeri sipil yang bersangkutan. Promosi berarti ada kenaikan peran dari sebelumnya seperti kenaikan pangkat atau jabatan dalam organisasi ataupun karena adanya nilai tanggungjawab terhadap pemanfaatan potensi dirinya, seperti untuk jabatan fungsional. Promosi adalah proses kenaikan jabatan yang berarti bahwa adanya perubahan kedudukan seorang pegawai dari jabatan yang rendah ke jabatan yang lebih tinggi dengan tugas dan tanggung jawab yang lebih besar. Dengan adanya promosi jabatan memberikan kesempatan kepada aparatur untuk menduduki suatu jabatan yang lebih tinggi. Promosi jabatan sebagai salah satu upaya pengembangan sumber daya aparatur haruslah dilakukan dengan memenuhi beberapa persyaratan sesuai dengan aturan yang telah ditentukan antara lain; kepangkatan, latar belakang pendidikan dan kinerja aparatur selama melaksanakan tugas pokoknya sebagai pegawai negeri sipil.

Pelaksanaan promosi jabatan merupakan klimaks dari pengembangan karier seorang pegawai, sebab justru individu-individu pegawai berkepentingan melanjutkan pendidikan dan mengikuti diklat, bahkan berprestasi karena dimotivasi oleh keinginan 
untuk mendapat posisi yang lebih baik dalam kariernya. Bahkan terjadinya geliat yang tinggi dalam tubuh administrasi kepegawaian umumnya dipicu oleh motivasi yang berlebihan dalam mendapatkan promosi jabatan yang baik, bahkan ada segelintir pegawai yang menggunakan cara-cara di luar peraturan perundang-undangan dalam mendapatkan jabatan tersebut seperti sistem nepotisme, kolusi ataupun cara-cara lain yang tidak lazim. Promosi biasanya dilakukan atau diberikan kepada pegawai yang membuktikan kesanggupan dan loyalitas kepada organisasi. Dengan adanya promosi berarti kenaikan jabatan yakni menerima keluasan dan tanggung jawab lebih besar dari sebelumnya. Pemberian promosi kepada seseorang pegawai berarti bahwa pegawai tersebut naik keposisi yang lebih tinggi dalam suatu struktur organisasi. Promosi tidak selalu diikuti oleh kenaikan gaji. Gaji bisa tetap, tetapi pada umumnya bertambah besar kekuasaan dan tanggug jawab seeorang bertambah juga balas jasanya dalam bentuk uang yang diterima. Dalam hal ini kenaikan upah tidak selalu dapat diartikan merupakan promosi. Pelaksanaan mutasi promosi pegawai, dalam arti pengangkatan dan pemindahan pegawai dalam suatu jabatan maka terdapat kewenangan yang cukup luas bagi pemerintah daerah Kabupaten Gowa di mana bahwa untuk pengangkatan dalam jabatan untuk eselon III ke bawah adalah merupakan kewenangan pemerintah daerah itu sendiri. Sedangkan untuk jabatan eselon II, maka Bupati kepala Daerah perlu berkonsultasi dengan Gubernur, hal ini sesuai dengan pasal 130 ayat 2 Undang-Undang Nomor 32 Tahun 2004 yang mengatakan bahwa pengangkatan, pemindahan dan pemberhentian dari dan dalam jabatan eselon II pada pemerintah daerah kabupaten/kota ditetapkan oleh Bupati/Walikota setelah berkonsultasi kepada Gubernur.

Dengan demikian bahwa untuk pimpinan SKPD (Satuan Kerja Pemerintah Daerah) seperti Dinas dan Badan yang berkedudukan sebagai eselon II b, maka dalam hal pengangkatannya perlu berkoordinasi dengan Gubernur dalam arti bahwa calon-calon pimpinan dinas dan badan yang dianggap memenuhi syarat dapat diajukan ke Gubernur untuk dikonsultasikan. Meskipun demikian dalam prakteknya bahwa umumnya pejabat yang diajukan untuk dikonsultasikan ke Gubernur adalah mereka telah masuk target pimpinan daerah, dalam hal ini oleh Bupati, dalam arti tentu ada muatan politik dalam arti ada alasan asas kepatutan dan azas kepatuhan di dalamnya. Hal ini berkaitan dengan 
loyalitasnya kepada Bupati selaku Kepala Daerah. Oleh sebab itu meskipun terdapat aturan dalam pemindahan dan pengangkatan pejabat eselon II, namun tentu pejabat Pembina kepegawaian di daerah sangat berwewenang untuk mendapatkan pejabat sesuai dengan harapan organisasinya.

Dengan adanya kewenangan yang cukup luas tersebut maka memungkinkan pemerintah Kabupaten Gowa untuk melakukan penyegaran struktur organisasi berdasarkan kebutuhan-kebutuhan organisasinya. Meskipun demikian, dalam hal pengangkatan dalam suatu jabatan, maka pemerintah daerah melalui Badan Kepegawaian dan Diklat Daerah tentu saja melakukan suatu analisis kompetensi jabatan untuk pengangkatan pegawai dalam suatu jabatan dimana hanya pegawai yang benar-benar memenuhi persyaratan yang dapat di angkat, dalam arti memenuhi syarat prestasi dan memenuhi syarat karier. Dari wawancara yang dilakukan dengan Kepala Bidang Perencanaan dan Mutasi PNS BKDD Kabupaten Gowa mengungkapkan bahwa penilaian pengangkatan pegawai dalam suatu jabatan eselon, maka seharusnya yang menjadi pertimbangan utama adalah kompetensi dan profesionalisme pegawai, namun tentu tidak bisa juga dilepaskan dengan faktor loyalitas berdasarkan penilaian dari pejabat yang akan menggunakan pegawai tersebut, sebab seluruh pelaksanaan tugas-tugas SKPD yang ada di Kabupaten Gowa tentu harus bertanggungjawab kepada Bupati melalui Sekwilda sebagaimana dalam tupoksi yang ada, sehingga meskipun ada pegawai yang secara kompetensi lebih bagus tapi belum tentu dapat diangkat sesuai harapan.

Berdasarkan penelitian yang dilakukan menunjukkan bahwa pelaksanaan promosi jabatan dan kepangkatan di lingkungan Pemerintah Daerah Kabupaten Gowa pada tahun 2012- 2013 telah dilaksanakan terhadap promosi untuk kenaikan pangkat / golongan yang berpengaruh kepada pegawai negeri sipil dalam rangka mutasi promosi jabatan. Di Kabupaten Gowa saat ini terdapat pegawai negeri sipil yang pada umumnya berada pada golongan III, sehingga dapat dipastikan bahwa cukup banyak pegawai negeri sipil yang bersedia untuk siap diangkat dalam suatu jabatan khususnya untuk eselon IV dan III, kondisi ini tentu membuat persaingan sumber daya aparatur yang cukup ketat dalam menempati posisi jabatan struktural. Dari wawancara yang dilakukan dengan Sub Bidang Mutasi Pegawai Negeri Sipil BKDD Kabupaten Gowa menyatakan banyaknya pegawai 
yang memperoleh golongan III dan IV di Kabupaten Gowa, merupakan bagian dari banyaknya pegawai pada antara 2008 - 2009 yang memperoleh kenaikan pangkat setiap tahun, bahkan ada pegawai yang naik pangkat pilihan; satu tahun dalam pangkat dan satu tahun dalam jabatan bagi pegawai negeri sipil yang memangku jabatan satu tingkat dibawa pangkat dasar sehingga ketersediaan pegawai untuk golongan III memang cukup banyak di Kabupaten Gowa.

Bahkan dari penelitian yang dilakukan maka ada beberapa pegawai yang menyatakan bahwa masa kerja mereka selaku pegawai negeri sipil baru 10 tahun dan diangkat pada golongan III a, namun saat ini telah berpangkat golongan IV a, dalam arti bahwa bila dihitung dari ketentuan perundang-undangan yang berlaku bahwa kenaikan pangkat regular pegawai adalah 4 tahun dan 2 tahun jabatan struktural, maka pegawai yang bersangkutan sejak dari awal hanya membutuhkan waktu setiap 2,5 tahun untuk masing-masing jenjang kepangkatan. Dalam hal pengangkatan jabatan struktural pegawai dalam suatu instansi pada dasarnya terjadi kewenangan secara berjenjang, di mana bahwa untuk level internal SKPD pihak yang berwewenang menilai pegawai yang akan dipromosikan adalah atasan langsung dari pegawai yang bersangkutan. Pegawai eselon IV akan dinilai dalam rapat yang melibatkan pegawai eselon III, sedangkan pegawai eselon III dinilai oleh Kepala Dinas atau Kepala Badan. Sedangkan pihak yang berwewenang untuk mempertimbangkan siapa yang akan dipromosikan adalah tim Baperjakat yang bersidang rata-rata dua kali dalam setahun. Berita acara dari sidang Baperjakat merupakan dokumen rahasia. Pegawai yang akan dipromosikan oleh Baperjakat tidak dilibatkan dalam sidang dan segera setelah keputusan dikeluarkan oleh Bupati, maka pegawai yang bersangkutan tidak mempunyai pilihan selain menerima surat keputusan tersebut.

\section{Sistem dan Prosedur Mutasi PNS Di Kabupatn Gowa}

Sebagaimana dijelaskan sebelumnya bahwa kewenangan pemerintah daerah dalam hal pengangkatan dan pemindahan pegawai di era otonomi daerah sangat luas sehingga dalam dalam hal mutasi pegawai negeri sipil umumnya sangat bergantung pada kemampuan dari pembina kepegawaian daerah itu sendiri meskipun demikian bukan tanpa batasan sebab pemerintah daerah tetap berpedoman pada sistem dan prosedur yang 
ada. Dalam pelaksanaan pembinaan dan pengembangan pegawai pada umumnya dan promosi jabatan pegawai yang pada dasarnya selalu berpedoman pada sistem pembinaan dan pengembangan yang ada dan sistem pembinaannya selalu didasarkan pada sistem prestai kerja dan sistem karier (Agustina et al., 2013). Di jajaran Pemerintah Daerah Kabupaten Gowa, pelaksanaan promosi jabatan baik jabatan struktural maupun jabatan fungsional selalu didasarkan pada sistem karier dan prestasi kerja. Sistem karier yaitu didasarkan pada pertimbangan masa kerja dari pegawai yang bersangkutan dalam jabatanjabatan tertentu serta pengalaman-pengalamanya selama memangku jabatan selaku pegawai negeri sipil. Dimana promosi dilakukan dengan mempertimbangkan pada tingkat prestasi, kecakapan dan keterampilan dalam menjalankan tugas-tugasnya yang dicerminkan pada Daftar Penilaian Prestasi Pegawai (DP3) (Wahyudi, 2014).

Sesuai dengan Peraturan Pemerintah Nomor 13 Tahun 2002 Tentang Pengangkatan Pegawai Negeri Sipil dalam Jabatan Struktural, maka pemerintah daerah diberi kewenangan untuk membentu Baperjakat (Badan Pertimbangan Jabatan dan Kepangkatan). Struktur Baperjakat ini juga mencerminkan kekuatan kewenangan yang ada di daerah, di mana Ketua Baperjakat adalah Sekretaris Daerah dan Sekretaris Baperjakat adalah Kepala BKDD, hasil kerja Baperjakat berujung pada keputusan Bupati (Pratamaputra et al., 2010). Oleh sebab itu, kewenangan-kewenangan dalam penilaian pengangkatan pegawai dalam suatu jabatan sebagaimana dijelaskan sebelumnya bahwa kecuali jabatan eselon II yang harus berkonsultasi dengan Gubernur, maka seluruh kewenangan pembinaan kepegawaian berada pada Kepala Pembina Kepegawaian Daerah dalam hal ini adalah Bupati Kepala Daerah.

Dalam hal sistem dan prosedur sebagaimana diketahui bahwa dalam pembinaan kepegawaian tentu masih dilakukan secara nasional, sehingga untuk prosedur ditetapkan berdasarkan petunjuk teknis dan petunjuk pelaksanaannya yang ditetapkan dengan Keputusan pemerintah. Jadi standar sistem prosedur pengangkatan pegawai dalam suatu jabatan adalah merupakan petunjuk yang diberikan oleh pemerintah pusat yang sebagaimana diatur dalam Peraturan Pemerintah Nomor 13 Tahun 2002 Tentang Pengangkatan Pegawai Negeri Sipil dalam Jabatan Struktural. Ketentuan mengenai sistem prosedur tersebut tetap mengacu pada Undang-Undang Nomor 43 Tahun 1999 yang 
menyebutkan bahwa pembinaan karier pegawai negeri sipil di dasarkan pada sistem karier dan sistem prestasi kerja.

Oleh sebab itu bahwa pertimbangan utama untuk menduduki jabatan-jabatan struktural dalam lingkup Pemkab Gowa adalah didasarkan pada prestasi kerja dan masa kerja pegawai dalam arti bahwa pembinaan dan pengembangan pegawai lebih diarahkan pada kemampuan, keterampilan serta kecakapan pegawai itu sebagaimana yang tertuang dalam syarat-syarat khusus dalam promosi jabatan berupa kompetensi manajerial dan kompetensi substantif. Dalam pelaksanaan promosi jabatan, maka harus tunduk pada Peraturan perundang-undangan yang ada termasuk kepada prosedur-prosedur kerja dari Badan Pertimbangan Jabatan dan Kepangkatan (BAPERJAKAT) yang merupakan suatu badan yang membantu Bupati dalam pengangkatan, pemindahan dan pemberhentian pegawai negeri sipil dari dan dalam jabatan struktural.

\section{KESIMPULAN}

Berdasarkan hasil penelitian maka dapat ditarik kesimpulan sebagai berikut: Dalam hal mutasi pegawai negeri sipil, maka kewenangan yang ada pada pemerintah sangat luas. Hanya pengangkatan eselon II yang perlu mendapatkan persetujuan dari pemerintah tingkat atasnya, dan pengangkatan Sekwilda yang mendapatkan persetujuan dari DPRD setempat. Semua pegawai negeri sipil yang akan diangkat dalam jabatan eselon III ke bawah dalam lingkup Pemerintah Daerah Kabupaten Gowa menjadi kewenangan pemerintah daerah. Oleh sebab itu dalam hal mutasi daerah Kabupaten Gowa, dapat dikatakan cukup mandiri dalam arti seluruh keputusan-keputusan mengenai pengangkatan pegawai dalam suatu jabatan berdasarkan kebutuhan ditetapkan sendiri oleh pemerintah daerah tanpa intervensi dari pemerintah tingkat atasnya. Prosedur untuk mutasi pegawai, berbeda sesuai dengan kedudukan dari mutasi tersebut. Untuk mutasi karena promosi, maka telah ditetapkan berdasarkan perundang-undangan yang berlaku, di mana terdapat persyaratan yang harus dipenuhi oleh pegawai yang akan di mutasi promosi sesuai dengan pertimbangan prestasi kerja dan karier yang dimiliki, dan mendapat proses dari BAPERJAKAT (Badan Pertimbangan Jabatan dan Pangkat) yang terdiri dari Sekretaris Daerah, Asisten Tata Praja, Asisten Administrasi, Kepala 
Inspektorat, Kepala Badan Kepegawaian dan Diklat Daerah dan Kepala Bidang Perencanaan dan Mutasi pegawai negeri sipil, jadi pelaksanaan mutasi di Kabupaten Gowa khususnya mutasi jabatan promosi di proses oleh BAPERJAKAT berdasarkan usulan dari Kepala SKPD masing-masing. Keluasan kewenangan daerah dalam melakukan mutasi terutama untuk promosi pegawai di lingkungan internalnya, maka disarankan perlu kinerja yang lebih tinggi dari Baperjakat melalui kewenagan pengawasan pembinaan kepegawaian oleh pemerintah. Agar kewenangan dan pengembangan kemandirian daerah dalam pengangkatan pegawai dalam jabatan sesuai dengan proses dan prosedur maka perlu di bentuk dewan etik kepegawaian, dengan kewenangan melakukan verifikasi kelayakan pengangkatan pegawai dalam suatu jabatan oleh pemerintah.

\section{REFERENSI}

Agustina, D. M., Sunarto, M. J. D., \& Jatmiko, K. 2013. Sistem Informasi Penilaian Kinerja Pegawai pada Badan Kepegawaian dan Diklat Surabaya. Jurnal Sistem Informasi Dan Komputer Akuntansi, 2(2), 1-6.

Bratakusumah, D. S. 2001. Otonomi penyelenggaraaan pemerintahan daerah: Deddy Supriady Bratakusumah, Dadang Solihin. Gramedia Pustaka Utama.

Fanhar, F. T. M. 2016. Kewenangan Penjabat Kepala Daerah Dalam Melaksanakan Mutasi Kepegawaian Dikota Bandar Lampung.

Judas, A. 2013. Mutasi Dan Promosi Jabatan Pengaruhnya Terhadap Prestasi Kerja Pegawai Pada Kanwil Ditjen Kekayaan Negara Suluttenggo Dan Maluku Utara Di Manado. Jurnal Riset Ekonomi, Manajemen, Bisnis Dan Akuntansi, 1(4), 12191228. https://doi.org/10.35794/emba.v1i4.2895

Karyana, A. 2014. Pengantar Ilmu Administrasi.

Krippendorf, K. 2004. Content Analysis: An Introduction To Its Methodology. Sage Publication.

Miles, M. B., \& Huberman, A. M. 1994. Qualitative data analysis: An expanded sourcebook. sage.

Pratamaputra, N. A. A., Hidayah, N. A., \& Waspodo, B. 2010. Sistem pendukung keputusan kenaikan jabatan dengan model ahp pada biro kepegawaian di sekretariat Negara Republik Indonesia. Studia Informatika: Jurnal Sistem Informasi, 3(1). 
Putro, B. S., \& Sugiyarti, S. R. 2012. Kemandirian Pengelolaan Mutasi Pns Antar Daerah Dalam Era Otonomi Daerah. Transformasi, 14(22).

Rahman, M. 2017. Ilmu Administrasi (Vol. 1). Sah Media.

Sani, S. 2016. Sejarah Perkembangan Otonomi Daerah Di Indonesia. Jurnal Criksetra, 5(9), 79-83. http://jurnal.untag-sby.ac.id/index.php/dih/article/view/278

Sarwono, E. 2011. Dan Dana Alokasi Umum ( Dau ) Terhadap Belanja Daerah Pada Kabupaten / Kota Se Indonesia Tahun Anggaran 2010-2011.

Satoto, S. 2004. Pengaturan Eksistensi dan Fungsi Badan Kepegawaian Negara. Universitas Airlangga.

Wahyudi, J. 2014. Penilaian Kinerja Pegawai Negeri Sipil (Kajian Pra Implementasi Peraturan Pemerintah Nomor 46 Tahun 2011 Tentang Penilaian Prestasi Kerja PNS Di Lingkungan Pemerintah Kabupaten Barito Timur). Jurnal Administrasi Publik Dan Birokrasi, 1(3), 72259.

Undang-undang Nomor 22 Tahun 1999

Undang-undang Nomor 32 Tahun 2004

Undang-Undang Nomor 43 Tahun 1999

Peraturan Pemerintah Nomor 13 Tahun 2002 